\title{
Clinical and Pathological Findings on Intoxication by Yellow Phosphorus After Ingesting Firework Cracker: A Rare Case of Autopsy
}

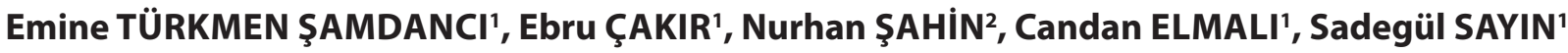 \\ 'Department of Pathology, Inönü University, Faculty of Medicine, MALATYA, TURKEY, \\ ${ }^{2}$ Department of Pathology, Malatya State Hospital, MALATYA, TURKEY
}

\begin{abstract}
Yellow phosphorus is a toxic substance used in the production of firework cracker, fireworks, ammunition and agricultural dung. When ingested, it shows its effects mainly in the liver, the kidneys, and the brain. A four-year-old girl had died as a result of acute hepatic failure caused by ingesting a firework cracker. The case showed high levels of hepatic enzymes, along with non-specific signs such as nausea, vomiting and diarrhea. Autopsy revealed diffuse microvesicular steatosis in the liver and disseminated degeneration in the proximal tubules of the kidneys. In cases with concomitant hepatorenal failure and cardiovascular collapse, death is inevitable. However, when only hepatic failure develops, hepatic transplantation may be lifesaving. Although intoxication from ingesting yellow phosphorus has a very high rate of mortality, forensic cases are extremely rare in the literature.
\end{abstract}

Key Words: Phosphorus, Hepatic failure, Fatty liver, Autopsy

\section{INTRODUCTION}

Death resulting from extraordinary causes, such as injuries caused by firearms or explosives, penetrating stab wounds, traffic accidents, falls, occupational accidents, intoxication, electric shock, lightning strikes and mechanic asphyxia, are considered to be forensic cases. In addition to providing medical aid to patients in such cases, physicians must determine whether the cases are forensic and, if they are, to notify the police as quickly as possible $(1,2)$. For our case of intoxication from yellow phosphorus following the ingestion of a firework cracker, the necessary medical intervention was performed in the emergency department of our hospital, and the case was recorded as forensic.

Yellow phosphorus is an inorganic substance used in the production of fireworks, firecrackers, ammunition and agricultural dung (3). Firework cracker is the name of an entertainment firework used in Turkey. These fireworks are chocolate brown in color, measure approximately $1 \mathrm{~cm}$ in diameter and emit a popping sound when rubbed against the ground (4). Firework cracker contains yellow phosphorus, red phosphorus, potassium chloride, iron oxide, silica, antimony substance and magnesium carbonate, all in varying amounts (5).

Because this firework can dissolve in fat and bile approximately 2 to 3 hours after it is absorbed in the

(Turk Patoloji Derg 2016, 32:51-53)

Received : 25.12.2011 Accepted : 30.01.2012 intestines, it starts to accumulate in the liver and leads to acute hepatic failure. The brain, heart, kidneys and pancreas are also affected, although to a lesser extent $(5,6)$. In cases where there is acute hepatic failure but multi-organ failure has not yet developed, liver transplantation may be lifesaving. However, the mortality rate remains very high (7).

The histopathological findings of the visceral organs were presented, along with clinical information, for our pediatric forensic case, in which acute hepatic failure developed because of yellow phosphorus after the accidental ingestion of firework cracker, causing death due to multi-organ failure.

\section{CASE REPORT}

A four-year-old girl with complaints of abdominal pain, nausea, vomiting and diarrhea was examined in the emergency department, at İnönü University's Faculty of Medicine, in Malatya, Turkey. Her parents reported that she had ingested firework cracker. She underwent nasogastric lavage. Foreign bodies observed in her gastric content included brown pieces that were thought to belong to firework cracker. In her biochemical tests, aspartate amino transferase (AST) was $928 \mathrm{u} / \mathrm{L}(5-40 \mathrm{u} / \mathrm{L})$ and alanine amino transferase (ALT) was $1043 \mathrm{u} / \mathrm{L}(7-56 \mathrm{u} / \mathrm{L})$. The patient had a total bilirubin of $5.74 \mathrm{mg} / \mathrm{dl}(1.0 \mathrm{mg} / \mathrm{dl})$ and

Correspondence: Emine TÜRKMEN ŞAMDANCI

İnönü Üniversitesi, Tip Fakültesi, Tibbi Patoloji Anabilim Dalı,

MALATYA, TURKEY

E-mail: turkmenmd@yahoo.com Phone: +90 5057813599 
was rapidly evaluated and diagnosed with acute hepatic failure. Because this was a case of intoxication, it was at the same time recorded as a forensic case and forensic authorities were notified. The general status of the patient, who was to undergo an immediate hepatic transplantation, deteriorated within hours and she was hospitalized in the intensive care unit. The patient developed encephalopathy and died as a result of cardiovascular collapse before undergoing liver transplantation. Autopsy was performed and no macroscopically significant pathological finding was detected in the organs, except for yellow discoloration in the liver. For histomorphological examination, tissue specimens obtained from the brain, liver, lungs, kidneys and pancreas were fixed in $10 \%$ formalin solution.

In the microscopic examination, congestion was noted in the brain, lungs and pancreas. In the hepatic sections, nearly all the hepatocytes showed macrovesicular and microvesicular vacuolization (Figure 1). Diffuse vacuoles, located in the hepatocytes, were positively stained with Oil Red O (Figure 2). There was no necrosis and inflammation in the liver. Periodic acid Schiff (PAS) and d- PAS did not reveal any metabolic substance accumulation. In sections of the kidney, the proximal tubular epithelium had generally fallen into in the lumen and showed a vacuolar appearance (Figure 3).

\section{DISCUSSION}

Yellow phosphorus is a toxic substance used in the production of firework cracker, fireworks, ammunition and agricultural dung (8). Yellow phosphorus intoxication is seen in developing countries, but rarely reported in developed countries. In developing countries, the intoxication generally results from unintentional oral ingestion $(9,10)$. Our case was intoxicated after she ingested firework cracker while she was playing.

The literature includes limited information about the damage yellow phosphorus can cause to tissue, although some case reports and a few experimental animal studies have shown it as a cause of acute hepatic failure (11). In some articles published under the topic of substance intoxication affecting the liver, yellow phosphorus is cited as an etiologic substance. In our case, the changes caused by yellow phosphorus in organs other than the liver, such as the brain, lungs, heart and kidneys, were macroscopically and microscopically examined. Orally ingested yellow phosphorus is rapidly absorbed through the gastrointestinal system and approximately $70 \%$ is accumulated in the liver within 2 to 3 hours. It accumulates to a lesser extent in the heart (12\%), kidneys (4\%), pancreas

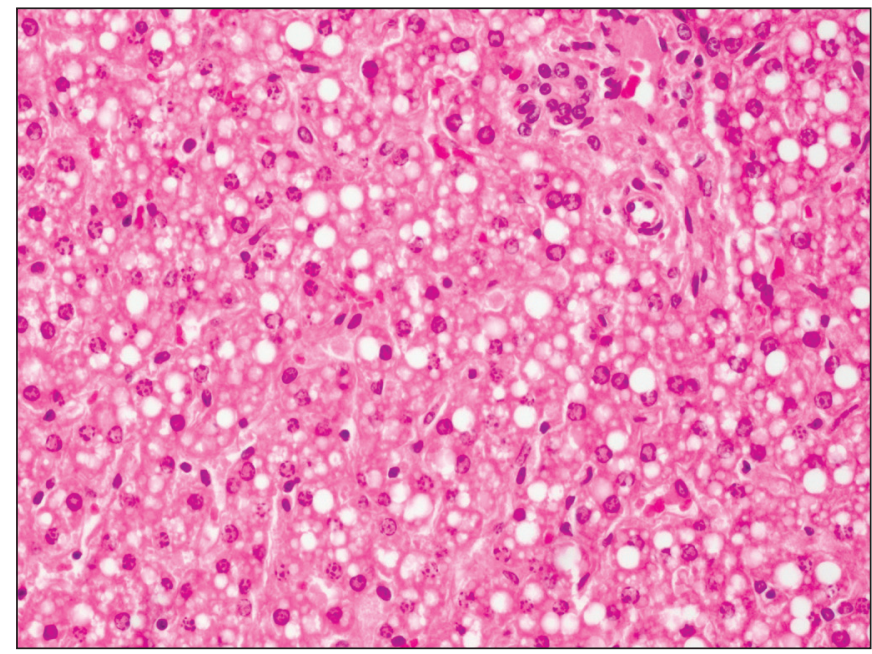

Figure 1: Vacuolar appearance of hepatocytes (H\&E, x400).

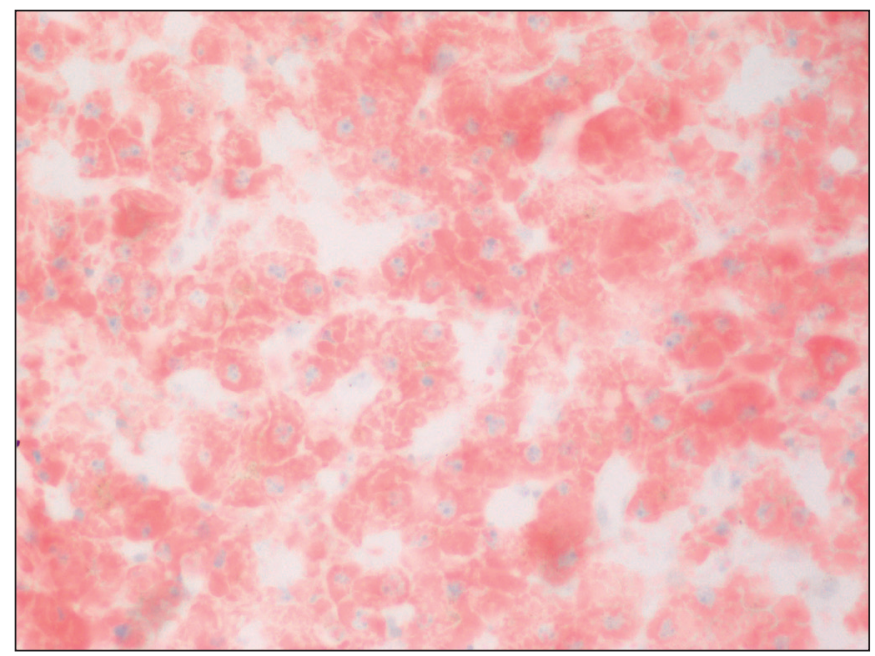

Figure 2: Diffuse fat globules (Oil red O, x400).

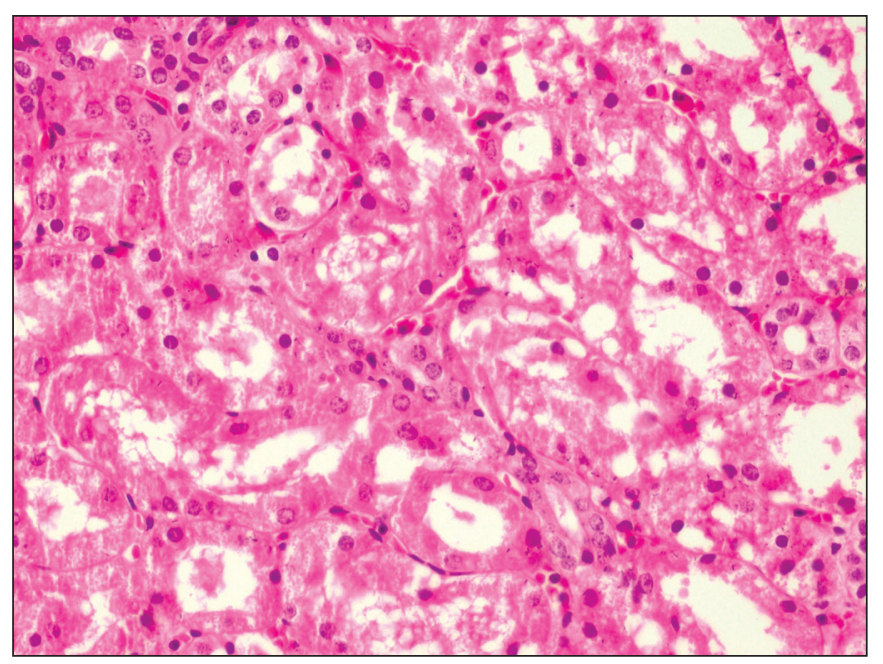

Figure 3: Vacuolar degeneration in the proximal tubular epithelium of the kidney (H\&E, x400). 
(0.4\%), and brain $(0.39 \%)$, and also leads to damage in those organs (12). Histopathological changes, in our case, were mainly detected in the liver and kidneys. No significant pathological change, other than congestion, was observed in the brain, lungs, pancreas and heart. As seen in the literature, marked histomorphological appearance, correlated with the clinical hepatic and renal findings, supported the fact that yellow phosphorus showed a greater accumulation in liver and kidneys. Again, the lack of a remarkable microscopic change in the heart and other organs was consistent with the literature and was directly proportional to the amount of yellow phosphorus digested. In addition, the fact that the patient died within hours may explain why few morphological changes were observed in organs other than the liver and kidneys.

Serious intoxication resulting from this substance follows a course that is accompanied by multi-system organ failures and has a mortality rate between $20 \%$ and $50 \%(12,13)$. In our case of intoxication resulting from yellow phosphorus and multiple organ failure, mainly of the liver, the course rapidly led to the patient's death.

Although yellow phosphorus has no antidote, supportive therapy is given (14). Our case underwent gastric lavage and was given supportive therapy to maintain the fluidelectrolyte balance. As liver transplantation can be lifesaving, in spite of the high rate of mortality in cases that develop acute hepatic failure (15), our patient died before hepatic transplantation could be performed.

Deaths, such as those resulting from murders, injuries caused by firearms, explosives and all other types of devices, traffic accidents, battery burns, falls, intoxication, electric shock and suicide attempts, that are presented to emergency departments at hospitals and health institutions are considered to be forensic cases (16). The case presented here was considered a forensic case because of the intoxication. The legal authorities were notified and an autopsy was performed at the request of the prosecution.

It is important to note that the firework cracker, which is produced and sold unchecked and used as amusement for children who live mainly in regions with lower sociocultural level, is one of the most common and fatal cause of fulminant hepatic failure. This report aimed at highlighting the importance of considering substance intoxications as forensic cases, of examining histomorphological changes caused in some tissues by yellow phosphorus intoxication, which has a high mortality, and of looking at the role of social factors in yellow phosphorus intoxication.

\section{REFERENCES}

1. Tuğcu H, Özdemir Ç, Dalgıç M, Ulukan MÖ, Celasun B. GATA Adli Tip Anabilim Dalı'nda 1995-2002 yılları arasında düzenlenen adli raporların yeni Türk Ceza Kanunu açısından değerlendirilmesi. Gülhane Tip Derg. 2005;47:102-5.

2. Yavuz MS, Ozguner IF. Süleyman Demirel Üniversitesi Tip Fakültesi Acil Servis'ine 1999-2001 yılları arasında müracaat eden adli olguların değerlendirilmesi. Adli Tip Derg. 2003;17: 47-53.

3. Nikkenen HE, Ewald MB. Phosphorus. In: Flomenbaum NE, Goldfrank LR, Hoffman RS, Howlans MA, Neal AL, Nelson LS. editors: Goldfrank's toxicologic emergencies. MC Graw-Hill; 2006.1487-97.

4. Akman SA, Cakir M, Baran M, Arikan C, Yuksekkaya HA, Tumgor G, Saz EU, Zeytunlu M, Kilic M, Aydogdu S. Liver transplantation for acute liver failure due to toxic agent ingestion in children. Pediatr Transplant. 2009;13:1034-40.

5. Ahishali E, Boynueğrı B, Dabak R, Dolapçioğlu C, Uygur Bayramıçlı O. A case of severe acute hepatitis due to oral intake of firecrackers. Turk J Gastroenterol. 2010;21(3):325-6.

6. Fernandez OU, Canizares LL. Acute hepatotoxicity from ingestion of yellow phosphorus-containing fireworks. J Clin Gastroenterol. 1995;21:139-42.

7. Ates M, Dirican A, Ozgor D, Aydin C, Isik B, Ara C, Yilmaz M, Selimoglu A, Kayaalp C, Yilmaz S. Living donor liver transplantation for acute liver failure in pediatric patients caused by the ingestion of fireworks containing yellow phosphorus. Liver Transpl. 2011;17:1286-91.

8. Eldad A, Simon GA. The phosphorous burn--a preliminary comparative experimental study of various forms of treatment. Burns. 1991;17:198-200.

9. Konjoyan TR. White phosphorus burns: case report and literature review. Milit Med. 1983;148:881-4.

10. Mozingo DW, Smith AA, McManus WF, Pruitt BA Jr, Mason AD Jr. Chemical burns. J Trauma Inj Crit Care. 1988;28:642-7.

11. Cameron JM, Patrick RS. Acute phosphorus poisoning--the distribution of toxic doses of yellow phosphorus in the tissues of experimental animals. Med Sci Law. 1966;6:209-14.

12. McCarron MM, Gaddis GP, Trotter AT. Acute yellow phosphorus poisoning from pesticide pastes. Clin Toxicol. 1981;18:693-711.

13. Santos O, Restrepo JC, Velásquez L, Castaño J, Correa G, Sepúlveda E, Yepes N, Hoyos S, Guzmán C, Osorio G, Cárdenas A. Acute liver failure due to white phosphorus ingestion. Ann Hepatol. 2009;8:162-5.

14. Brent J, Wallace K. Phosphorus. In: Brent J, Wallace K, Buckhart $\mathrm{K}$, editors. Critical care toxicology: Diagnosis and management of the critically poisoned patient. Philadelphia: Elsevier Saunders; 2005. 851-61.

15. Polson J, Lee WM. AASLD Position paper: The management of acute liver failure. Hepatology. 2005;41:1179-97.

16. Beyaztaş FY. Adli rapor konusunda hekim sorumluluğu. Anadolu Psikiyatri Derg. 2000;1:231-4. 